einstein

Official Publication of the Instituto Israelita

de Ensino e Pesquisa Albert Einstein

ISSN: 1679-4508 | e-ISSN: 2317-6385

\title{
Comment to:
}

\section{Intensive support recommendations for critically-ill patients with suspected or confirmed COVID-19 infection}

Comentário para:

\author{
Recomendações de suporte intensivo para pacientes graves \\ com infecção suspeita ou confirmada pela COVID-19
}

Thiago Domingos Corrêa', Gustavo Faissol Janot de Matos', Bruno de Arruda Bravim', Ricardo Luiz Cordioli', Alejandra del Pilar Gallardo Garrido', Murillo Santucci Cesar de Assuncao', Carmen Silvia Valente Barbas ${ }^{1}$, Karina Tavares Timenetsky', Roseny dos Reis Rodrigues', Hélio Penna Guimarães', Roberto Rabello Filho', Frederico Polito Lomar', Farah Christina de La Cruz Scarin', Carla Luciana Batista', Adriano José Pereira', João Carlos de Campos Guerra', Bárbara Vieira Carneiro', Ricardo Kenji Nawa', Rodrigo Martins Brandão', Antônio Eduardo Pereira Pesaro', Moacyr Silva Júnior', Fabricio Rodrigues Torres de Carvalho', Cilene Saghabi de Medeiros Silva', Ana Claudia Ferraz de Almeida', Marcelo Franken'1, Marcele Liliane Pesavento', Raquel Afonso Caserta Eid', Leonardo José Rolim Ferraz'

${ }^{1}$ Hospital Israelita Albert Einstein, São Paulo, SP, Brazil.

DOI: 10.31744/einstein_journal/2020CE5931

Dear Editor,

In this issue of einstein journal (São Paulo), Corrêa et al., reported intensive support recommendations for critically-ill patients with suspected or confirmed infection by the new coronavirus (COVID-19). ${ }^{(1)}$ Based on preliminary demonstration of efficacy of chloroquine, the authors suggested the use of hydroxychloroquine in monotherapy or combined with a macrolide (azithromycin or clarithromycin), to treat severe patients with COVID-19, admitted to the intensive care unit (ICU), to inhibit in vitro replication of severe acute respiratory syndrome coronavirus 2 (SARS-CoV-2). ${ }^{(2)}$

However, evidence from observational studies ${ }^{(3,4)}$ involving hospitalized COVID-19 patients demonstrated the use of hydroxychloroquine in monotherapy ${ }^{(3)}$ or combined with a macrolide ${ }^{(4)}$ was not associated with reduced mortality when compared to patients who did not receive such medications (controls). Yet, the use of hydroxychloroquine in monotherapy or combined with a macrolide may be associated with greater incidence of major cardiovascular complications. ${ }^{(4)}$

Therefore, based on new evidence available, we exclude the recommendation to use hydroxychloroquine in monotherapy or combined with a macrolide for treating inpatients with severe acute respiratory syndrome caused by COVID-19.

\section{Copyright 2020}

\section{(c) By}

This content is licensed

under a Creative Commons

Attribution 4.0 International License.
How to cite this article:

Corido AG. Assuncao MS, et al. Comment einstein (São Paulo) 2020:18:eCE5931. http://dx.doi.org/10.31744/einstein_journal/

Corresponding author:

Comingos Corrêa

$5^{\circ}$ andar - Morumbi

Phone: (55 11) 2151-0603

E-mail: thiago.correa@einstein.br 


\section{AUTHORS' INFORMATION}

Corrêa TD: http://orcid.org/0000-0001-9546-3910 Matos GF: http://orcid.org/0000-0001-9996-7040 Bravim BA: http://orcid.org/0000-0001-8290-8554 Cordioli RL: http://orcid.org/0000-0001-7521-399X Garrido AG: http://orcid.org/0000-0002-2469-185X Assuncao MS: http://orcid.org/0000-0002-0741-4869 Barbas CS: http://orcid.org/0000-0002-3922-6256 Timenetsky KT: http://orcid.org/0000-0002-4176-2445 Rodrigues RR: http://orcid.org/0000-0002-3796-5952 Guimarães HP: http://orcid.org/0000-0001-5523-1015 Rabello Filho R: http://orcid.org/0000-0001-7018-224X Lomar FP: http://orcid.org/0000-0002-7856-0716 Scarin FC: http://orcid.org/0000-0001-5724-6448 Batista CL: http://orcid.org/0000-0001-8628-0792 Pereira AJ: http://orcid.org/0000-0002-9467-6516 Guerra JC: http://orcid.org/0000-0002-4156-529X Carneiro BV: http://orcid.org/0000-0001-7858-9730 Nawa RK: http://orcid.org/0000-0002-0852-7013 Brandão RM: http://orcid.org/0000-0003-1442-9097 Pesaro AE: http://orcid.org/0000-0003-3133-4989 Silva Júnior M: http://orcid.org/0000-0002-6479-1708 Carvalho FR: http://orcid.org/0000-0001-8712-269X Silva CS: http://orcid.org/0000-0003-3544-6646 Almeida AC: http://orcid.org/0000-0002-5339-0415 Franken M: http://orcid.org/0000-0002-4286-8559 Pesavento ML: http://orcid.org/0000-0001-7391-8208 Eid RA: http://orcid.org/0000-0002-8241-3241 Ferraz LJ: http://orcid.org/0000-0003-1822-1568

\section{REFERENCES}

1. Corrêa TD, Matos GF, Bravim BA, Cordioli RL, Garrido AD, Assuncao MS, et al. Intensive support recommendations for critically-ill patients with suspected or confirmed COVID-19 infection. einstein (São Paulo). 2020;18:eAE5793.

2. Liu J, Cao R, Xu M, Wang X, Zhang H, Hu H, et al. Hydroxychloroquine, a less toxic derivative of chloroquine, is effective in inhibiting SARS-CoV-2 infection in vitro. Cell Discov. 2020;6:16. doi: 10.1038/s41421-020-0156-0

3. Geleris J, Sun Y, Platt J, Zucker J, Baldwin M, Hripcsak G, et al. Observational study of hydroxychloroquine in hospitalized patients with Covid-19. N Engl J Med. 2020;382(25):2411-8.

4. Rosenberg ES, Dufort EM, Udo T, Wilberschied LA, Kumar J, Tesoriero J, et al. Association of treatment with hydroxychloroquine or azithromycin with in-hospital mortality in patients with COVID-19 in New York State. JAMA. 2020;323(24):2493-502. 